\title{
Perbandingan Pemberian Metoprolol Tartrat dengan Lidokain secara Intravena terhadap Perubahan Tekanan Darah dan Laju Nadi Akibat Tindakan Laringoskopi dan Intubasi
}

\author{
Yovita Koswara, Erwin Pradian, Ike Sri Redjeki \\ Departemen Anestesiologi dan Terapi Intensif \\ Fakultas Kedokteran Universitas Padjadjaran/Rumah Sakit Dr. Hasan Sadikin Bandung
}

\begin{abstract}
Abstrak
Tindakan laringoskopi dan intubasi endotrakeal dapat menyebabkan tekanan darah dan laju nadi naik secara mendadak akibat rangsangan terhadap sistem simpatis. Tujuan penelitian ini untuk mengetahui pengaruh pemberian metoprolol $5 \mathrm{mg}$ intravena dibandingkan dengan lidokain $1,5 \mathrm{mg} / \mathrm{kgBB}$ untuk mengurangi lonjakan hemodinamik akibat laringoskopi intubasi. Penelitian ini dilakukan secara uji klinis acak terkontrol buta ganda terhadap 40 pasien dengan status fisik American Society of Anesthesiologist (ASA) I-II yang menjalani operasi dengan teknik anestesi umum di Rumah Sakit Dr. Hasan Sadikin Bandung dari bulan Juli-Agustus 2013. Subjek dibagi menjadi 2 kelompok, yaitu kelompok yang diberikan metoprolol $5 \mathrm{mg}$ intravena atau lidokain 1,5 mg/kgBB 3 menit sebelum tindakan laringoskopi dan intubasi. Data penelitian dianalisis dengan uji-t, dengan nilai $\mathrm{p}<0,05$ dianggap bermakna. Analisis statistik menunjukkan bahwa pada 2 menit dan 3 menit setelah intubasi antara kedua kelompok didapatkan perbedaan bermakna pada seluruh parameter hemodinamik dengan nilai $\mathrm{p}<0,05$. Simpulan dari penelitian ini adalah metoprolol $5 \mathrm{mg}$ secara intravena memberikan hasil lebih baik dibandingkan dengan lidokain $1,5 \mathrm{mg} / \mathrm{kgBB}$ dalam hal mengurangi lonjakan hemodinamik akibat tindakan laringoskopi intubasi.
\end{abstract}

Kata kunci: Intubasi, laringoskopi, lidokain, metoprolol

\section{Comparison of Blood Pressure and Heart Rate Changes in Intravenous Metoprolol Tartrate and Lidocaine Use During Laryngoscopy and Intubation}

\begin{abstract}
Laryngoscopy and endotracheal intubation are associated with a sudden rise in blood pressure and pulse rate due to the stimulation of sympathetic activities. The aim of this study was to compare the effectiveness of intravenous $5 \mathrm{mg}$ metoprolol and lidocaine $1.5 \mathrm{mg} / \mathrm{kgBW}$ into attenuatinge hemodynamic response evoked by laryngoscopy and intubation. This was an experimental randomized double blind controlled trial study conducted to 40 patients with American Society of Anesthesiologist (ASA) physical status I or II who underwent surgery under general anesthesia in Dr, Hasan Sadikin General Hospital Bandung from July to August 2013. Subjects were divided into two groups; those who received $5 \mathrm{mg}$ intravenous metoprolol and those who received lidocaine $1.5 \mathrm{mg} / \mathrm{kgBW} 3$ minutes before laryngoscopy and intubation procedures. All data were analyzed using t-test, with a $p$ value $<0.05$ considered significant. Statistical analysis showed that on the second and third minutes after intubation and laryngoscopy, a significant difference in hemodynamic parameters was seen between the two groups with a $\mathrm{p}$ value $<0.05$. It is concluded in this study that intravenous $5 \mathrm{mg}$ metoprolol is better than lidocaine $1.5 \mathrm{mg} / \mathrm{kgBW}$ in attenuating thee hemodynamic responses evoked by laryngoscopy and intubation
\end{abstract}

Key words: Intubation, laryngoscopy, lidocaine, metoprolol

Korespondensi: Yovita Koswara, dr., SpAn, Departemen Anestesiologi dan Terapi Intensif Fakultas Kedokteran UniversitasPadjadjaran/RumahSakitDr. HasanSadikin Bandung,Jl.Rasamala No.3Bandung 40114, Mobile 08122388894, Emailyov96@yahoo.com 


\section{Pendahuluan}

Seorang anestesiolog sering dihadapkan pada prosedur operasi yang memerlukan anestesia umum untuk menjaga jalan napas agar selalu bebas. Prosedur laringoskopi dan juga intubasi endotrakeal, yaitu memasukkan suatu pipa ke dalam saluran napas bagian atas adalah salah satu usaha untuk mengamankan jalan napas dan merupakan salah satu tindakan yang rutin dalam anestesia umum. ${ }^{1-4}$

Laringoskopi serta intubasi mengakibatkan rangsangan yang besar dan stress respons yang berupa respons simpatoadrenal. Laringoskopi dan intubasi menyebabkan terjadi peningkatan kadar adrenalin serta noradrenalin yang akan mengakibatkan tekanan darah serta laju nadi naik secara mendadak. ${ }^{1-4}$ Peningkatan tekanan intrakranial, tekanan intraokular, serta spasme laring sangat berpotensi untuk menimbulkan bahaya,juga dapatmengakibatkan peningkatan laju nadi yang dihubungkan dengan perubahan segmen ST pada elektrokardiografi (EKG) yang mengindikasikan iskemik miokardium. ${ }^{5}$

Respons kenaikan tekanan darah serta laju nadi umumnya terlihat jelas selama tindakan laringoskopi dan manipulasi epiglotis. Tekanan darah sistol dapat meningkat $45 \%$ serta akan diikuti peningkatan laju nadi yang umumnya berupa sinus takikardia, peningkatan tekanan diastol yang dapat terjadi mencapai $24 \%$ saat tindakan laringoskopi serta $36 \%$ saat tindakan laringoskopi dan intubasi. ${ }^{6,7}$

Kejadian respons simpatis akibat tindakan laringoskopi serta intubasi endotrakeal telah menjadi perhatian untuk para ahli anestesia selama lebih dari 40 tahun terakhir. ${ }^{8}$ Berbagai usaha telah dilakukan dengan berbagai tingkat keberhasilan dalam rangka untuk mengurangi respons hemodinamik akibat laringoskopi dan intubasi, antara lain dengan cara meningkatkan tingkat kedalaman anestesia, pemberian obat antiinflamasi nonsteroid, lidokain, opioid, beta blocker, atau obat antihipertensi lain. ${ }^{13,6,7}$

Mendalamkan anestesia menggunakan gas anestesia inhalasi memiliki kerugian terjadi depresi miokardium dan juga masa pemulihan semakin panjang sejalan dengan peningkatan konsentrasi gas anestesia inhalasi tersebut. ${ }^{8}$ Penggunaan lidokain untuk menekan respons hemodinamik akibat laringoskopi dan intubasi telah banyak dipergunakan untuk mengurangi respons peningkatan tekanan darah dan laju nadi pada pasien yang menjalani pembedahan berencana dengan anestesia umum.

Penelitian menyatakan bahwa lidokain 1,5 $\mathrm{mg} / \mathrm{kgBB}$ secaraintravena mampu mengurangi respons hemodinamik akibat dari laringoskopi dan intubasi, ${ }^{3}$ namun terdapat pula penelitian yang menyatakan bahwa efek lidokain hanya mampu mencegah kejadian kenaikan tekanan darah, namun tidak mencegah kenaikan laju nadi akibat tindakan laringoskopi dan intubasi ini. $^{9}$

Pemberian golongan beta blocker sebagai pilihan untuk menekan respons hemodinamik akibat tindakan laringoskopi dan juga intubasi telah dilakukan. Hasil suatu penelitian yang menggunakan beta blocker untuk mengurangi respons rangsang simpatis terhadap tindakan laringoskopi serta intubasi, menyatakan bahwa penggunaan beta blocker dapat meminimalisir peningkatan laju nadi dan juga kontraktilitas miokardium dengan cara menekan efek positif kronotropik dan inotropik yang meningkatkan aktivitas adrenergik. ${ }^{8,10-12}$

Selain penelitian tersebut di atas, terdapat juga penelitian yang membandingkan 2 (dua) jenis sediaan beta blocker, beta blocker dengan opioid, beta blocker dengan lidokain, dan beta blocker, lidokain, serta opioid untuk menekan respons hemodinamik akibat laringoskopi dan intubasi. .,13-18 $^{8}$

Pada tahun 2002 telah dilakukan penelitian terhadap 60 orang pasien dengan status fisik American Society of Anesthesiologist (ASA) I-II yang menjalani pembedahan dengan intubasi endotrakeal, yang membandingkan efektivitas pemberian esmolol dengan metoprolol untuk mengurangi respons hemodinamik pada saat laringoskopi dan intubasi, menyatakan bahwa metoprolol $4 \mathrm{mg}$ secara intravena bolus dosis tunggal dapat menekan respons hemodinamik namun tidak pada seluruh sampel penelitian, yaitu hanya $80 \%$ dari seluruh sampel yang mendapatkan metoprolol. ${ }^{8}$

Pada tahun 2011 telah dilakukan penelitian 
yang membandingkan pemberian esmolol dan fentanil, didapatkan hasil bahwa penggunaan beta blocker intravena bolus efektif mengurangi peningkatan laju nadi dan juga tekanan darah akibat tindakan laringoskopi serta intubasi. ${ }^{14}$ Penelitian lain tahun 2005 terhadap 34 pasien membandingkan efektivitas antara fentanil 2 $\mu / \mathrm{kgBB}$ intravena dan metoprolol $40 \mu / \mathrm{kgBB}$ secara intravena untuk menurunkan respons hemodinamik akibat laringoskopi dan intubasi pada pasien hipertensi, pada hasil penelitian ini didapatkan bahwa metoprolol dan fentanil efektif dalam menekan respons hemodinamik tersebut. ${ }^{13}$

Sediaan beta blocker intravena yang sudah ada di Rumah Sakit Dr. Hasan Sadikin Bandung adalah metoprolol dan ternyata obat ini belum digunakan secara umum. Belum ada penelitian yang membandingkan penggunaan metoprolol dengan lidokain terhadap kenaikan tekanan darah dan laju nadi yang diakibatkan tindakan laringoskopi serta intubasi, karena itu peneliti tertarik untuk melakukan penelitian mengenai hal tersebut.

Pemilihan metoprolol $5 \mathrm{mg}$ secara intravena ialah berdasarkan penelitian sebelumnya yang menyatakan bahwa penggunaan metoprolol bolus dosis $4 \mathrm{mg}$ efektif mencegah peningkatan tekanan darah serta laju nadi akibat tindakan laringoskopi dan intubasi namun tidak pada seluruh sampel.

Penelitian ini bertujuan untuk mengetahui pengaruh pemberian metoprolol secara bolus intravena bila dibandingkan dengan lidokain secara intravena untuk mencegah peningkatan tekanan darah serta laju nadi akibat tindakan laringoskopi dan intubasi.

\section{Subjek dan Metode}

Penelitian ini dilakukan dengan cara prospektif eksperimental, dengan menggunakan uji acak terkontrol butaganda (double blind randomized controlled trial). Subjek penelitian ini adalah seluruh pasien yang menjalani operasi elektif dengan teknik anestesia umum yang dilakukan tindakan laringoskopi dan intubasi di Rumah Sakit Dr. Hasan Sadikin Bandung yang dimulai dari bulan Juli-Agustus 2013. Kriteria inklusi adalah pasien dengan status fisik American Society of Anesthesiologist (ASA) I-II, berusia 20-50 tahun. Kriteria eksklusi adalah pasien yang diperkirakan akan mengalami kesulitan intubasi, wanita hamil, pasien yang menderita penyakit kardiovaskular (termasuk hipertensi, dan hipotensi), mendapatkan pengobatan yang dapat memengaruhi tekanan darah serta laju nadi (antihipertensi, antiaritmia, beta blocker, stimulan jantung) yang kontraindikasi dengan obat-obatan yang digunakan, dan juga pasien dengan tekanan tinggi intrakranial. Kriteria pengeluaran bila tindakan laringoskopi serta intubasi diulang lebih dari 1 kali, waktu yang dibutuhkan untuk laringoskopi serta intubasi lebih dari 45 detik, dan juga terjadi penurunan tekanan darah serta laju nadi $>20 \%$ setelah pemberian obat anestesia.

Besar sampel ditentukan mempergunakan rumus perbedaan proporsi efektivitas antara 2 tindakan didapatkan jumlah sampel adalah 18 untuk tiap kelompok perlakuan, kemudian ditambahkan 10\% kemungkinan pengeluaran, sehingga jumlah sampel tiap kelompok adalah 20 orang dan jumlah seluruh sampel adalah 40 orang. Pemilihan subjek penelitian menurut consecutive sampling sesuai urutan datangnya pasien yang memenuhi kriteria inklusi serta tidak termasuk eksklusi dengan besar sampel minimal. Alokasi subjek ke dalam perlakuan berdasarkan randomisasi blok.

Setelah disetujui oleh Komite Etik Penelitian Kesehatan Rumah Sakit Dr. Hasan Sadikin Bandung/Fakultas Kedokteran Universitas Padjadjaran, pasien yang memenuhi kriteria inklusi diberikan penjelasan tentang prosedur yang akan dilaksanakan serta menandatangani persetujuan (informed consent). Pasien dibagi dalam dua kelompok secara randomisasi blok, yaitu kelompok I (M) mendapatkan metoprolol $5 \mathrm{mg}$ intravena (i.v.) dalam spuit $10 \mathrm{~mL}$, serta kelompok II (L) mendapatkan lidokain 1,5 mg/ kgBB i.v. dalam spuit $10 \mathrm{~mL}$, yang diberikan secara perlahan.

Saat pasien di ruang persiapan, dilakukan pemasangan infus dan juga pemberian cairan Ringer laktat (RL) 10 mL/kgBB selama 15-20 menit, lalu pasien dimasukkan ke dalam kamar 
operasi, dan dipasang alat pemantau tekanan darah noninvasif, EKG, dan juga pulse oxymetri. Pencatatan dilakukan terhadap parameter laju jantung, tekanan darah sistol, diastol, dan tekanan arteri rata-rata, sebagai data dasar pasien (waktu T00). Induksi dimulai dengan memberikan metoprolol $5 \mathrm{mg}$ atau lidokain 1,5 $\mathrm{mg} / \mathrm{kgBB}$ sesuai dengan kelompok perlakuan. Pasien diberikan preoksigenasi dengan oksigen $100 \%$, kemudian dilakukan induksi dengan propofol $2 \mathrm{mg} / \mathrm{kgBB}$ serta atrakurium 0,5 mg/ kgBB sebagai pelumpuh otot. Saat pasien tidak bernapas lagi akibat pelumpuh otot, diberikan oksigen $100 \%$ melalui ventilasi tekanan positif dan dipertahankan normoventilasi.

Dua menit kemudian dilakukan pencatatan parameter kardiovaskular yang merupakan pengukuran sesaat sebelum laringoskopi dan intubasi (waktu T0). Sesudah itu, dilakukan tindakan laringoskopi dengan menggunakan laringoskop Macintosh sesuai dengan ukuran danintubasi endotrakeal dengan menggunakan pipa endotrakeal sesuai dengan ukuran pasien. Tindakan ini dikerjakan dalam waktu tidak boleh lebih dari 45 detik dan hanya satu kali kesempatan. Sesaat setelah intubasi dilakukan pencatatan parameter kardiovaskular (waktu T1). Pemeliharaan anestesia mempergunakan $50 \% \mathrm{~N}_{2} \mathrm{O}$ dan $\mathrm{O}_{2}$ dengan gas isofluran $1,5 \mathrm{vol} \%$. Ventilasi kendali diberikan dan dipertahankan dalam keadaan normoventilasi. Pengukuran terhadap parameter kardiovaskular dilakukan pada menit ke-1, 2, 3, 4, dan 5 setelah intubasi (waktu T1-T5). Selama pencatatan, tindakan manipulasi pembedahan apapun belum boleh dimulai, baru setelah data pengukuran terakhir didapat, pembedahan boleh dimulai dan kedua kelompok dapat diberikan anestesia inhalasi dan juga obat-obat anestesia lain, misal opioid untuk pemeliharaan anestesi yang selanjutnya sesuai dengan kebutuhan serta pembedahan yang akan dilakukan.

Datapenelitian dianalisis denganujistatistik mempergunakan uji-t untuk membandingkan perbedaan dua rata-rata, uji chi-kuadrat untuk membandingkan perbedaan 2 (dua) proporsi data kualitatif, dan Uji Mann-Whitney untuk membandingkan median skor antara kedua kelompok. Analisis dengan tingkat kemaknaan yang dipilih 5\%, artinya apabila nilai $\mathrm{p}<0,05$ maka perbedaan tersebut bermakna menurut statistika.

\section{Hasil}

Penelitian dilakukan terhadap 40 pasien yang menjalani operasi dengan anestesi umum yang dibagi menjadi duakelompok,yaitu kelompok M yang mendapatkan metoprolol $5 \mathrm{mg}$ intravena, serta kelompok L yang mendapatkan lidokain $1,5 \mathrm{mg} / \mathrm{kgBB}$ melalui intravena. Karakteristik umum subjek penelitian kedua kelompok tidak berbeda bermakna (Tabel 1).

Tekanan darah sistol rata-rata praanestesi (T00) kelompok M sebesar 125,8 $( \pm 6,37)$ dan kelompok L 122,2 $( \pm 6,75)$ dengan perbedaan tidak bermakna menurut statistika $(p>0,05)$. Begitu pula dengan hasil tekanan darah sistol pasien setelah dilakukan induksi (T0). Pada saat satu menit setelah tindakan laringoskopi intubasi (T1) dan juga 2 menit setelahnya (T2) terdapat perbedaan yang bermakna $(p<0,05)$,

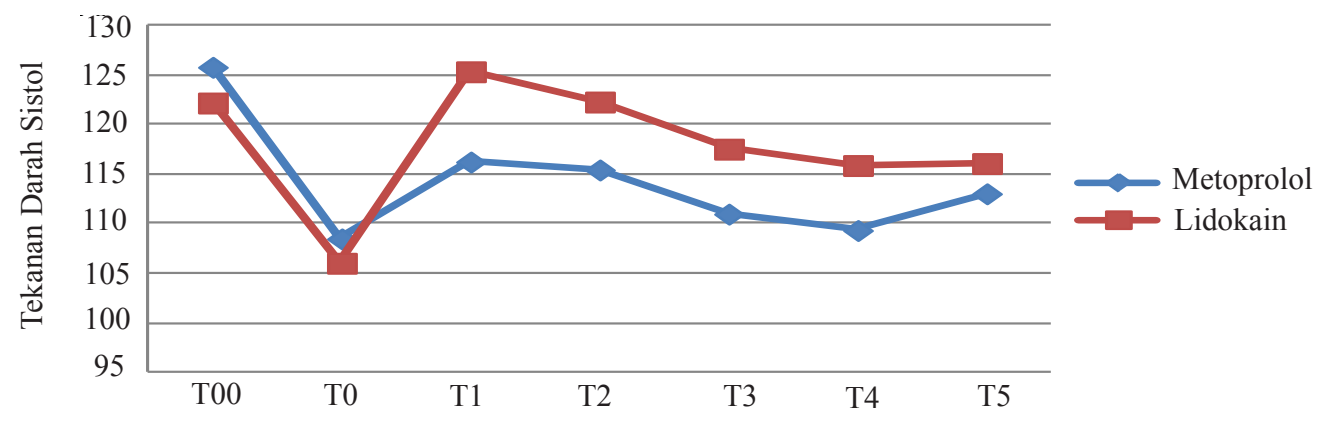

Gambar 1 Perbandingan Tekanan Darah Sistol pada Kedua Kelompok Perlakuan 
Tabel 1 Karakteristik Umum Subjek Penelitian

\begin{tabular}{lccccc}
\hline \multirow{2}{*}{ Variabel } & \multicolumn{3}{c}{ Kelompok } & \multirow{2}{*}{ p } \\
\cline { 2 - 5 } & M (n=20) & SB & L (n=20) & SB & \\
\hline Usia (tahun) & 30,67 & 5,89 & 31,56 & 6,31 & 0,647 \\
Tinggi badan (cm) & 160,89 & 6,03 & 158,70 & 6,35 & 0,223 \\
Berat badan (kg) & 55,18 & 5,31 & 57,59 & 5,08 & 0,095 \\
Tekanan darah sistol praanestesi (mmHg) & 125,80 & 6,37 & 122,2 & 6,75 & 0,091 \\
Tekanan darah diastol praanestesi (mmHg) & 74,45 & 8,40 & 68,65 & 13,01 & 0,102 \\
Tekanan arteri rata-rata praanestesi (mmHg) & 93,8 & 8,64 & 88,65 & 9,46 & 0,080 \\
Laju nadi praanestesi (x/menit) & 81,5 & 11,70 & 83,4 & 7,99 & 0,552 \\
\hline
\end{tabular}

Keterangan: bermakna $(\mathrm{p}<0,05)$. Nilai $p$ dihitung berdasarkan uji-t (usia dan berat badan). SB: simpangan baku

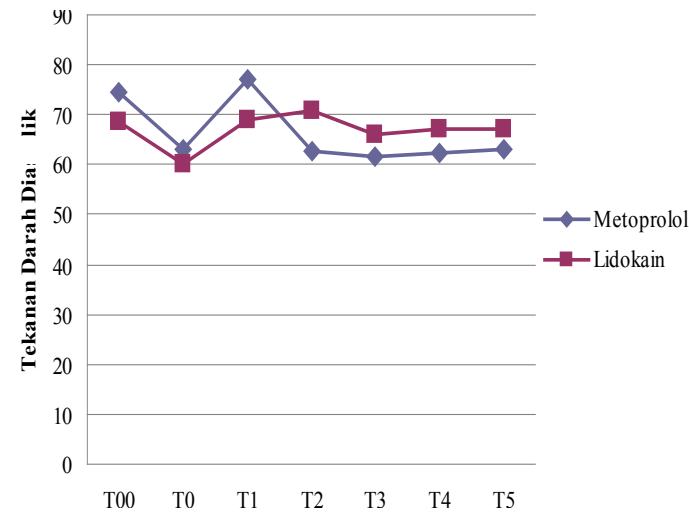

Gambar 2 Perbandingan Tekanan Darah Diastol pada Kedua Kelompok Perlakuan

sedangkan pada 3 menit (T3), 4 menit (T4), dan 5 menit (T5) setelah laringoskopi intubasi tidak terdapat perbedaan bermakna $(\mathrm{p}>0,05$; Gambar 1).

Tekanan darah diastol saat praanestesia (T00) dan setelah induksi (T0) pada kelompok $M$ dan $L$ tidak terdapat perbedaan bermakna ( $p>0,05$ ), namun pada 1 (satu) menit setelah intubasi (T1) serta dua menit setelah intubasi (T2) terdapat perbedaan bermakna $(\mathrm{p}<0,05$; Gambar 2).

Tekanan arteri rata-rata saat praanestesia (T00) dan setelah induksi (T0) pada kelompok $M$ dan L tidak memiliki perbedaan bermakna ( $p>0,05)$, tetapi pada saat satu menit setelah intubasi (T1) serta dua menit setelah intubasi (T2) terdapat perbedaan bermakna $(\mathrm{p}<0,05$; Gambar 3).

Laju nadi pasien saat pranestesi (T00) dan

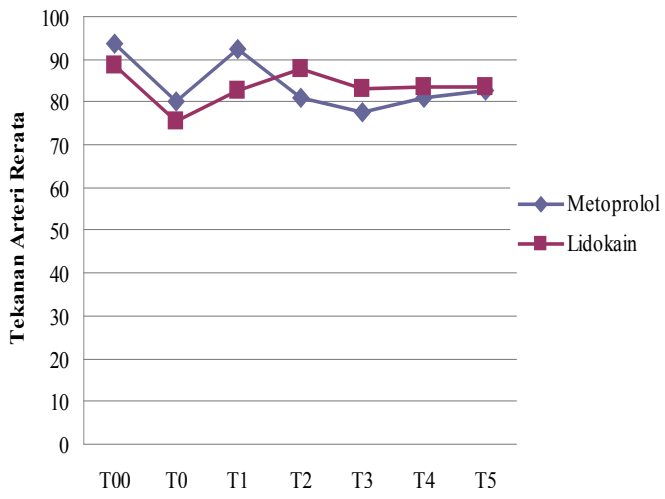

Gambar 3 Perbandingan Tekanan Arteri Ratarata pada Kedua Kelompok Perlakuan

setelah induksi anestesi (T0) pada kelompok $M$ dan L tidak memiliki perbedaan bermakna ( $p>0,05)$, namun pada 1 menit (T1), 2 menit (T2), dan 3 menit (T3) setelah intubasi terdapat perbedaan bermakna $(p<0,05$; Gambar 4).

\section{Pembahasan}

Usaha untuk mencegah respons hemodinamik berlebihan akibat intubasi endotrakeal adalah hal penting yang harus diperhatikan dalam rangka mencegah morbiditas akibat tindakan laringoskopi intubasi. Pemberian metoprolol 5 mg melalui intravena maupun lidokain $1,5 \mathrm{mg} /$ kgBB intravena diharapkan dapat mencegah respons hemodinamik yang diakibatkan oleh laringoskopi dan intubasi pada pasien yang akan menjalani anestesia umum.

Pada penelitian ini mempergunakan subjek 


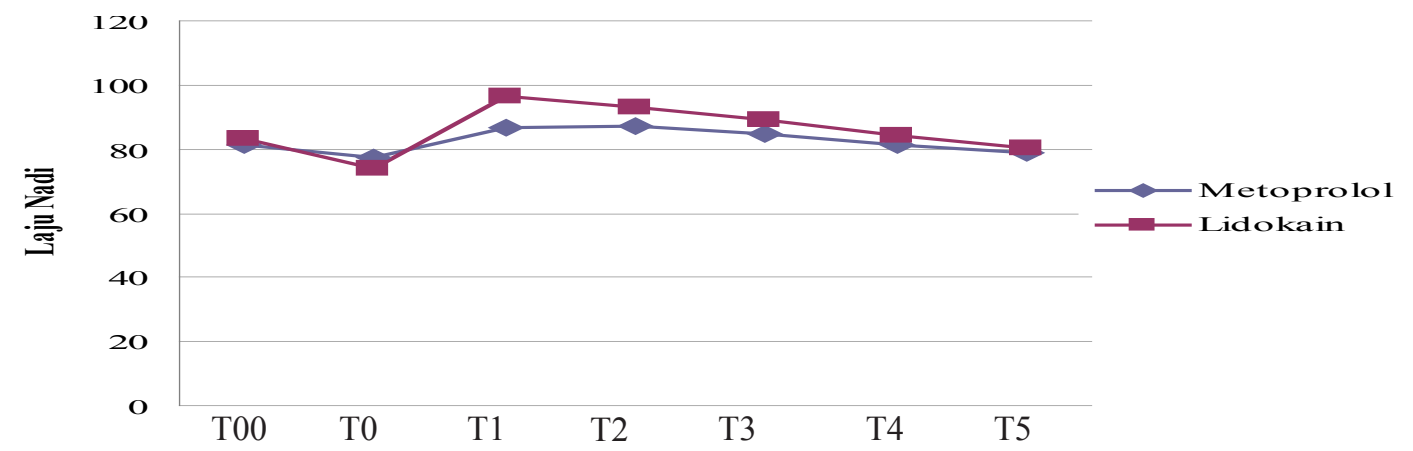

Gambar 4 Perbandingan Laju Nadi pada Kedua Kelompok Perlakuan

yang sama, yaitu 40 orang pasien dengan status fisik ASA I-II. Berdasarkan data karakteristik kelompok metoprolol dan kelompok lidokain tidak menunjukkan perbedaan yang bermakna dalam hal usia, tinggi badan, berat badan, dan hemodinamik saat awal (tekanan darah sistol, tekanan darah diastol, tekanan arteri rata-rata serta laju nadi) sehingga pasien secara statistik homogen dan layak dibandingkan (Tabel 1).

Tindakan laringoskopi dan intubasi yang mengakibatkan respons kardiovaskular telah diteliti selama lebih dari 30 tahun. Laringoskopi dan intubasi menimbulkan rangsangan yang cukup besar yang ditandai dengan respons simpatoadrenal sehingga meningkatkan kadar adrenalin dan noradrenalin dalam darah yang pada akhirnya meningkatkan tekanan darah dan laju nadi. ${ }^{1,2}$

Pada penelitian ini dilakukan pencatatan hemodinamik terdiri atas tekanan darah sistol, diastol, tekanan arteri rata-rata, dan laju nadi pada saat pasien masuk kamar operasi (T00), satu menit sebelum intubasi setelah induksi obat-obat anestesia (T0), serta setiap menit sampai 5 menit setelah intubasi (T1-T5). Hasil penelitian menunjukkan tekanan darah sistol, diastol, dan tekanan arteri rata-rata pada saat pasien masuk kamar operasi (T00) serta satu menitsebelumintubasi (T1) terjadipenurunan walaupun tidak menunjukkan perbedaan yang bermakna pada kedua kelompok perlakuan.

Penurunan tekanan yang terjadi tidak lebih dari $20 \%$ dari pengukuran dasar sehingga semua sampel termasuk dalam kriteria inklusi. Penurunan nilai tekanan darah sistol, diastol, serta tekanan arteri rata-rata tersebut diakibatkan oleh depresi sistem kardiovaskular serta sistem saraf autonom akibat obat-obat induksi anestesia. Pada 1 (satu) menit setelah tindakan laringoskopi dan intubasi (T1) dan 2 menit setelahnya terdapat perbedaan yang bermakna $(\mathrm{p}<0,05)$, sedangkan pada 3 menit (T3), 4 menit (T4), dan 5 menit (T5) setelah laringoskopi serta intubasi antara kelompok metoprolol dan lidokain tidak ada perbedaan bermakna ( $p>0,05)$.

Laju nadi saat praanestesi (T00) dan setelah induksi anestesi (T0) antara metoprolol dan kelompok lidokain tidak memiliki perbedaan yang bermakna $(p>0,05)$, namun pada 1 menit (T1) setelah laringoskopi dan intubasi terdapat perbedaan yang sangat bermakna $(\mathrm{p}<0,001)$, serta pada 2 menit(T2) dan 3 menit(T3) setelah laringoskopi dan intubasi terdapat perbedaan yang bermakna $(p<0,05)$. Penurunan laju nadi pada kelompok metoprolol antara nilai dasar dan setelah induksi anestesi sebesar 5,15\%, sedangkan pada kelompok lidokain sebesar 11,27\% (Gambar 4).

Pada saat setelah intubasi (T1) serta menit ke-2 setelah intubasi (T2) semua pengukuran baiktekanan darah sistol,tekanan darah diastol, tekanan arteri rata-rata, dan laju nadi terjadi peningkatan pada kedua kelompok perlakuan. Hasil ini sesuai dengan penelitian sebelumnya yang menyatakan peningkatan yang bermakna tekanan sistol, diastol, serta laju nadi terjadi 1 (satu) menit setelah tindakan laringoskopi yang dilanjutkan intubasi endotrakeal. Begitu juga konsentrasi adrenalin serta noradrenalin 
meningkat secara bermakna setelah 1 menit, konsentrasi dopamin meningkat 3-5 menit setelah laringoskopi maupun laringoskopi dan intubasi. ${ }^{19,20}$

Pada menit ke-2 hingga menit ke-5 setelah intubasi (T2-T5), pada kedua kelompok terjadi penurunan walaupun tidak bermakna tekanan darah sistol, diastol, tekanan arteri rata-rata, dan laju nadi. Hal ini didukung dari penelitian sebelumnya yang menyatakan bahwa tekanan darah sistol, diastol, tekanan arteri rata-rata, serta laju nadi akan menurun secara bertahap mencapai nilai sebelum tindakan laringoskopi dan intubasi setelah 5 menit.

Tindakan laringoskopi intubasi merupakan rangsangan nosiseptif pada laring serta trakea. Mekanisme terjadinya respons kardiovaskular akibat manipulasi pada jalan napas ini dimulai dengan suatu respons proprioseptor terhadap iritasi ataupun kerusakan jaringan di daerah supraglotis dan juga trakea. Rangsang mekanik akibat dari tindakan laringoskopi dan intubasi tersebut akan merangsang kemoreseptor dan mekanoreseptor di saluran napas. Selanjutnya, saraf glosofaringeal dan juga eferen vagus akan menghantarkan rangsangan ke daerah batang otak sehingga mengakibatkan aktivasi sistem saraf autonom termasuk sistem saraf simpatis serta parasimpatis. Melalui perantara nervus akselerator pada kardiak serta rantai ganglion simpatis, terjadi pelepasan norepinefrin dari terminal saraf adrenegik dan sekresi epinefrin dari medula adrenal yang akan meningkatkan tekanan darah dan laju nadi.

Hemodinamik pada kelompok metoprolol bila dibandingkan dengan hemodinamik awal (T00), didapatkan pada menit pertama setelah intubasi (T1) tidak terjadi peningkatan yang bermakna, demikian juga dengan menit-menit selanjutnya hingga menit ke-5 setelah intubasi. Demikian pula hasil pada kelompok lidokain, bila dibandingkan dengan nilai hemodinamik awal (T00), didapatkan pada menit pertama dan ke-2 setelah intubasi (T1 dan T2) terjadi peningkatan bermakna tekanan darah sistol, diastol, tekanan arteri rata-rata, dan laju nadi.

Perubahan tekanan sistol, diastol, tekanan arteri rata-rata, serta laju nadi antara kedua kelompok yang terjadi pada menit pertama
(T1) hingga menit ke-5 (T5) setelah intubasi terdapat perbedaan yang bermakna $(\mathrm{p}<0,05)$. Hal tersebut menunjukkan bahwa pemberian metoprolol $5 \mathrm{mg}$ bolus melalui jalur intravena maupun lidokain $1,5 \mathrm{mg} / \mathrm{kgBB}$ saat sebelum laringoskopi dan intubasi dapat menghambat kenaikan pada tekanan darah sistol, diastol, tekanan arteri rata-rata, serta laju nadi akibat laringoskopi serta intubasi, namun hasil yang lebih baik adalah pada kelompok metoprolol.

Hasil penelitian pada tahun 2002 yang telah membandingkan efek antara metoprolol dan esmolol secara intravena terhadap perubahan tekanan darah serta laju nadi akibat tindakan laringoskopi intubasi endotrakeal pada pasien dengan hipertensi yang terkontrol didapatkan bahwa penggunaan metoprolol akan menekan perubahan tekanan darah dan juga laju nadi akibat laringoskopi intubasi, penurunan laju nadi 3 menit setelah laringoskopi dan intubasi, serta penurunan tekanan darah sistol 5 menit setelah tindakan laringoskopi dan intubasi. ${ }^{8}$

Lidokain intravena telah diteliti berulangulangdalam hal untukmengurangi peningkatan tekanan darah serta laju nadi. Pada penelitianpenelitian tersebut menunjukkan hasil yang bervariasi dikarenakan oleh perbedaan dosis yang diberikan dan metode pemberian (baik laringotrakeal, aerosol atau intravena), serta waktu pemberian (baik 1, 2, 3, atau 5 menit sebelum intubasi).

Metoprolol memiliki harga jual yang lebih tinggi dibandingkan dengan lidokain, namun pemberiannya dapat dijadikan pertimbangan untuk mencegah respons hemodinamik yang berbahaya untuk pasien dengan faktor risiko seperti hipertensi atau penyakit jantung lain yang memerlukan tindakan laringoskopi dan intubasi, karena akan memberikan hasil yang

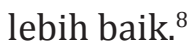

\section{Simpulan}

Berdasarkan analisis statistika hasil penelitian serta pembahasan, maka diperoleh simpulan bahwa pemberian metoprolol $5 \mathrm{mg}$ intravena mempunyai efek yang lebih baik dibandingkan dengan lidokain 1,5 mg/kgBB secara intravena 
dalam hal mencegah kenaikan tekanan darah akibat laringoskopi dan intubasi. Pemberian metoprolol 5 mg secara intravena mempunyai efek lebih baik dibandingkan dengan lidokain $1,5 \mathrm{mg} / \mathrm{kgBB}$ intravena dalam hal mencegah kenaikan laju nadi sebagai akibat laringoskopi dan juga intubasi. Pemberian metoprolol $5 \mathrm{mg}$ intravena dapat mengurangi lonjakan tekanan darah sistol, diastol, dan tekanan arteri ratarata akibat tindakan laringoskopi dan intubasi.

\section{Daftar Pustaka}

1. Steven A, JB M, FB R. Physiologic and pathophysiologic responses to intubation. Dalam: Carin A, penyunting. Benumof's airway management. Edisi ke-2. Philadelphia: Mosby Elsevier; 2007. hlm. 194-207.

2. Stoelting R, Miller R, Airway management and tracheal intubation. Dalam: Ronald D. Miller, Ronald D, penyunting. Miller Robert $K$. Stoelting basics of anesthesia. Edisi ke4. New York: Churchill Livingstone Inc; 2000. hlm. 148-66.

3. Stoelting R. Circulatory changes during direct laryngoscopy and tracheal intubation: influence of duration of laryngoscopy with or without prior lidocaine. Anesthesiology. 1977;47(4):381 -4 .

4. Morgan E, Mikhail M, Murray M. Airway management. Cinical anesthesiology. New York: McGraw-Hill Companies; 2006.

5. Barham N, Boomers O, Sherry K, Locke T. Myocardial ischaemia during tracheal extubation in patients after cardiac surgery: an observational sudy. BJA. 1998; 80:832-3.

6. Shribman A, Smith G, Achola J. Cardiovascular and catecholamine responses to laryngoscopy with and without tracheal intubation. BJA. 1987;59: 295-9.

7. Hassan H, El-Sharkawy $\mathrm{T}$, Rench $\mathrm{H}$, Mansour G, Fouda A. Hemodynamic and catecholamine responses to laryngoscopy with vs without endotracheal intubation.
Acta Anaestheol Scand. 1991;35:442-7.

8. Zargar J, Naqash I, Gurcoo S, Din M. Comparative evaluation of the effect of metoprolol and esmolol on rate pressure product and ECG changes during laryngoscopy and endotracheal intubation in controlled hypertensive patients. Indian J Anaesth. 2002;46(5):365-8.

9. Stoelting R. Blood pressure and heart rate changes during short duration laryngoscopy for tracheal intubation: influence of viscous or intravenous lidocaine. Anesth Analg. 1978;57:197-9.

10. Yoruko D, Goktug A, Alano Z, Tulunay M. Comparison of intravenous metoprolol, verapamil and diltiazem on the attenuation of haemodynamic changes associated with tracheal extubation. EJA. 1999;16(7):4627.

11. Singh S, Quadir A, Malhotra P. Comparison of esmolol and labetolol in low dose for attenuation of sympathomimetic response to laryngoscopy and intubation. SJA. 2010;4(3):163-8.

12. Singh M, Vichitvejpaisal P, Gaines G, White P. Comparative effect of lidocaine, esmolol, and nitroglycerin in modifying the hemodynamic response to laryngoscopy and intubation. J Clin Anaesth. 1995;7:5-8.

13. Zhang F, Fang Y. Effects of metoprolol and fentanyl on circulatory response to tracheal intubation in hypertensive patients. Chinese J Anaesth. 2005;4:1-15.

14. Gupta S, Tank P. A comparative study of efficacy of esmolol and fentanyl for pressure attenuation during laryngoscopy and endotracheal intubation. SJA. 2011; 5(1):12-8.

15. Magnusson J, Werner O, Carlsson C, Norden $\mathrm{N}$, Pettersson K. Metoprolol, fentanyl and stress responses to microlaryngoscopy. Effects on arterial pressure, heart rate and plasma concentration of catecholamines, ACTH and cortisol. BJA. 1983;55(5):40514.

16. Kapuangan C, Farida R, Perdana A. Respons kardiovaskular pada tindakan laringoskopi dan intubasi orotrakea perbandingan antara bolus intravena esmolol $100 \mathrm{mg}$ 
dengan lidokain. Anest and Crit Care. 2008 ;26:139-46.

17. Levitt M, Dresden G. The efficacy of esmolol versus lidocaine to attenuate the hemodynamic responses to intubation in isolated head trauma patients. Acad Emerg Med. 2001;8:19-24.

18. Ugur B, Ogurlu M, Gezer E, Aydin ON, Gursoy F. Effects of esmolol, lidocaine and fentanyl on haemodynamic responses to tracheal intubation. A comparative study. Clin Drug Invest. 2007;27(4):269-77.
19. Roberts CP, Greene LT, Meloche R, Foex P. Studies of anaesthesia in relation to hypertension II: haemodynamic consequences of induction and endotracheal intubation. $\mathrm{Br} \mathrm{J}$ Anaesth. 1998;80:106-22.

20. Pathak D, Slater R, Ping S. Effects of alfentanil and lidocaine on the hemodynamic responses to laryngoscopy and tracheal intubation. J Clin Anesth. 1990;2(2):81-5. 